\title{
Global styring for god helse
}

\author{
Internasjonale politiske forhandlinger og økonomiske avtaler kan påvirke nasjonale helsesystemer i negativ \\ eller positiv retning. Universitetet i Oslo har i samarbeid med The Lancet og Harvard Global Health Institute \\ etablert en kommisjon som skal gi anbefalinger om hvordan folkehelsen mer effektivt kan beskyttes og \\ promoteres i politiske nøkkelsektorer.
}

Det siste tiåret har det vært et inntog av nye aktører, både offentlige og private, på feltet global helse (1). Koordinert innsats er vanskelig. God styring på globalt plan kan sikre at lokal og nasjonal folkehelse beskyttes mot politiske, sosiale og økonomiske krefter som utfordrer universelle helseidealer (2).

\section{Mektige politiske sektorer}

Økende flyt av mennesker, varer, kunnskap og teknologiske fremskritt har ført til at verden er blitt én sfære. Mennesker i ulike geografiske områder påvirkes av de samme problemene, og deler utfordringer. Det er økende forståelse for at globale forhandlings- og styringsprosesser innen sikkerhetspolitikk, handel, miljø, utdanning, landbruk og migrasjon i stor grad påvirker helsesektoren. Internasjonale avtaler om patentrettigheter begrenser nasjonale myndigheters mulighet til å påvirke konkurranseforhold og prissetting, og kan dermed utgjøre en barriere for fattige befolkningers tilgang til essensielle medisiner. Globale normer for tobakkskontroll som legger til rette for nasjonalt påslag av tobakksavgifter, eller legitimerer krav om merking av produkter som volder alvorlig helseskade, har hatt positiv effekt på folkehelsen. Samtidig ser vi at de samme normene utfordres av sterke markedskrefter.

Mektige politiske sektorer, som utenrikspolitikk, finans, og handel har stor innflytelse på faktorer som påvirker folkehelsen. Samtidig har helsesektoren bare begrenset innflytelse på beslutninger i disse sektorene som direkte eller indirekte har helseeffekter. Helsespørsmål kommer ofte i konflikt med tvingende krav fra myndigheter og sterke interessegrupper, for eksempel til militær opprustning, energibruk og økonomisk utnyttelse og vekst. Forhandlingene om en bindende klimaavtale er ett eksempel på at politikk utenfor helsesektoren har stor betydning for folkehelsen (3), hvor kortsiktige økonomiske interesser prioriteres på bekostning av tiltak med helsefremmende effekt.

\section{En kommisjon for global styring}

Norges utenriksminister, Jonas Gahr Støre, har tatt til orde for at helse bør få større plass i utformingen av utenrikspolitikk og globale styringsprosesser. I Oslo-deklarasjonen fra 2007 uttrykker utenriksministre fra Brasil, Indonesia, Sør-Afrika, Thailand,

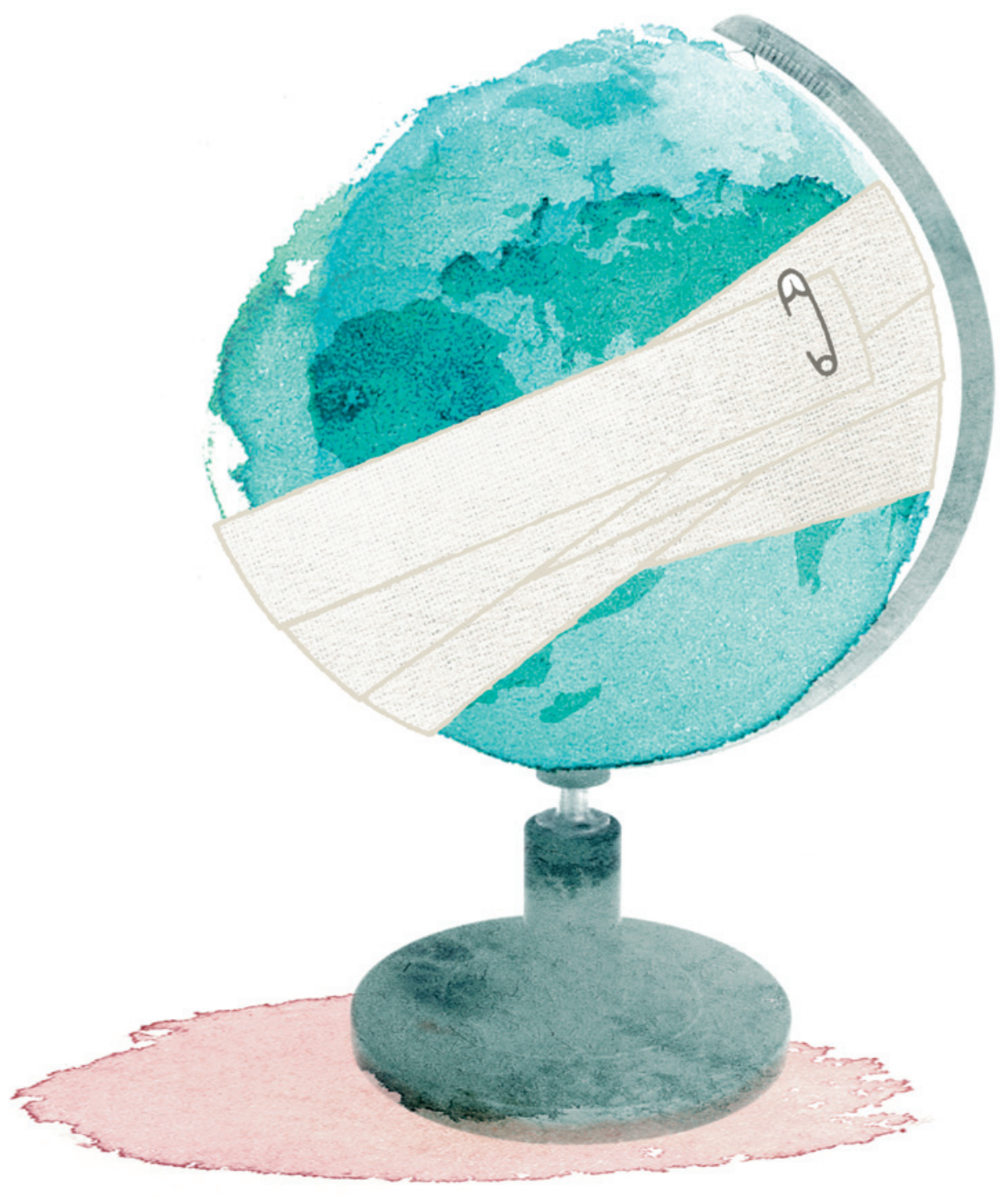

Illustrasjon (c) Supernøtt popsløyd

Senegal, Frankrike og Norge at utenrikspolitikken er en nøkkelfaktor for å løse globale helseutfordinger (4). Tre år senere, i desember 2010, etterlyste Støre en sektoroverskridende analyse som ledd i en: «...academic commission on global governance for health to promote innovative thinking that would move beyond conventional wisdom» (5).

Det er med dette som bakteppe at «The Lancet-University of Oslo Commission on Global Governance for Health» - i sam- arbeid med Harvard Global Health Institute - er blitt etablert (6). Kommisjonen utgjør en uavhengig akademisk ekspertgruppe som har til formål å: «analyse the inter-relations between health and other governance sectors, to assess how policies and actions in these areas affect global health objectives and hence identify how targeted actions outside institutions of health governance may contribute to global health.»

Kommisjonsarbeidet skal resultere i konkrete anbefalinger om hvordan folke- 
helsen mer effektivt kan beskyttes og promoteres i nøkkelsektorer.

Kommisjonen består av 16 forskere og eksperter fra alle verdensdeler, med bakgrunn fra ulike fagområder som er relevant for styresett og helse. Kommisjonærene skal utføre arbeidet over en periode på to år. Rektor ved Universitetet i Oslo, Ole Petter Ottersen, leder kommisjonen, og kommisjonen inngår som et ledd i Universitetet i Oslos handlingsplan for internasjonalisering 2012-14. Innsatsen er forankret gjennom et sekretariat ved universitetet som koordinerer arbeidet. Vi jobber i dette sekreteriatet, som skal sørge for utarbeiding av endelig rapport i The Lancet. Dertil er det opprettet en ressursgruppe som fungerer som tenketank og bidrar med oppdaterte forskningsrapporter og annen støtte rekvirert av kommisjonen.

En periode på to år med spennende arbeid har nå begynt. Vi håper at dette initiativet kan bidra med ny kunnskap og tenkning om hvordan global styring for helse kan fungere, slik at folkehelsen lokalt, nasjonalt og globalt kan ivaretas på en mer rettferdig og bærekraftig måte.

\section{Unni Gopinathan}

unni.gnathan@gmail.com

Ann Louise Lie

Just Haffeld

Harald Siem

Instiutt for helse og samfunn

Universitetet i Oslo
Unni Gopinathan (f. 1986) er medisinstudent ved Universitetet i Oslo og rådgiver til i sekretariatet for The Lancet - University of Oslo Commission on Global Governance for Health i samarbeid med Harvard Global Health Institute (Lancet-UiO kommisjonen). Han har tidligere vært International Federation of Medical Students' Associations utsending til Verdens Helseorganisasjon (WHO), har hospitert i WHO og vært «Duke Global Health Fellow» gjennom Duke Sanford School of Public Policys sommerprogram i Genève.

Forfatter har fylt ut ICMJE-skjemaet og oppgir ingen interessekonflikter.

Ann Louise Lie (f. 1985) er prosjektkoordinator i Sekretariatet til Lancet-UiO kommisjonen og har en master i Public Policy med spesialisering i helse og utvikling fra Maastricht University. Forfatter har fylt ut ICMJE-skjemaet og oppgir ingen interessekonflikter.

Just Haffeld (f. 1972) er jurist, Master of Negotiation and Conflict Resolution fra La Trobe University i Melbourne og sisteårs medisinstudent ved Det medisinske fakultet, Universitetet i Oslo. Han er rådgiver til sekretariatet for Lancet-UiO kommisjonen. Han er også tilknyttet O'Neill Institute of National and Global Health Law ved Georgetown University, USA, der han jobber med globale helsespørsmål.

Forfatter har fylt ut ICMJE-skjemaet og oppgir ingen interessekonflikter.
Harald Siem (f. 1941) er ansatt ved Avdeling for global helse, Helsedirektoratet. Han har vært distriktslege på Aukra, har arbeidet ved Institutt for allmennmedisin ved Universitetet i Oslo,

i Oslo helseråd, Arbeidsgiverforeningen og i ti år med internasjonalt helsearbeid i Genève.

Forfatter har fylt ut ICMJE-skjemaet og oppgir ingen interessekonflikter.

\section{Litteratur}

1. Møgedal S, Alveberg B, Pereira C. Den globale helsearkitekturen - til nytte for alle? Tidsskr Nor Legeforen 2011; 131: 1660-2.

2. Marmot M, Friel S, Bell R et al. Closing the gap in a generation: health equity through action on the social determinants of health. Lancet 2008; 372: $1661-9$.

3. Kvåle G, Fadnes LT, Tryland M et al. Klimaendrin ger - vår tids største helsetrussel. Tidsskr Nor Legeforen 2011; 131: 1670-2.

4. Oslo Ministerial Declaration-global health: a pressing foreign policy issue of our time. Lancet 2007; 369: 1373-8.

5. Støre JG. Health and foreign policy. Boston: Kennedy Forum. Harvard Kennedy School, 2010. http://www.regjeringen.no/nb/dep/ud/aktuelt/ taler artikler/utenriksministeren/2010/ helse harvard $\mathrm{htm}$ l? id =627344 (13,1.2011)

6. Universitetet i Oslo. Institute of health and society The Lancet - UiO Commission: Global Governance for Health. www.uio.no/global-governance-health (1.2. 2012).

Mottatt 17.1. 2012, første revisjon innsendt 6.2. 2012, godkjent 9.2. 2012. Medisinsk redaktør Siri Lunde.

\section{Ansvarsforsikring - jeg?}

\section{8 år gammel er jeg ikke lenger lege. Det er noe jeg en gang var. Hvorfor trenger jeg da ansvarsforsikring?}

Jeg er alderspensjonert lege, i mitt 78. år. Jeg tok embetseksamen i Oslo i 1960, og gikk av med alderspensjon etter henimot 41 yrkesaktive år. Jeg sluttet helt med pasientbehandling da jeg ble pensjonist, og hadde således intet grunnlag for å søke om forlengelse av noe som helst. Da jeg passerte 75 , forsvant også «den siste rest» av rett til å forskrive medikamenter. Når det var behov for øyedråper, måtte barnebarna heretter få dem forskrevet av annen lege. Det er slik det er.

Det jeg imidlertid ikke forstår, er at jeg $i$ alle årene, også etter fylte 75 - også nå i 2012, fra Legeforeningen er blitt avkrevet penger for å dekke ansvarsforsikring. Jeg har årlig betalt, med stigende undring. Hva er det jeg som lege ansvarsforsikres for? Jeg bærer ikke noe ansvar som lege. Jeg er ikke lege. Det er noe jeg var engang. Nå bærer jeg slikt ansvar som vi alle har som borgere og medmennesker.

Men ansvarsforsikring, avkrevet av Legeforeningen? Kan det virkelig være så ille at Legeforeningen med dette formidler en holdning som «Engang lege, alltid lege». Det ville i så fall være alarmerende. Jeg synes jeg hører «neida, det er egentlig ikke fordi du er ansvarsforsikret, det er for å dekke ditt abonnement på Tidsskriftet».
Om så skulle være tilfellet,- kanskje Legeforeningen kunne si det som det er?

\section{Christian Fangel \\ Oslo}

Christian Fangel (f. 1934) er pensjonert psykiater.

Ingen oppgitte interessekonflikter.

Mottatt 21.2. 2012 og godkjent 2.3. 2012. Medisinsk redaktør Anne Kveim Lie. 